\title{
Penanganan Pelayanan Kesehatan Di Masa Pandemi Covid-19 Dalam Perspektif Hukum Kesehatan
}

\author{
Moch Halim Sukur, Bayu Kurniadi, Haris, Ray Faradillahisari N \\ Fakultas Hukum Universitas Trunojoyo \\ Rayfaradillahisarin98@gmail.com
}

\begin{abstract}
Abstrak
Pada bulan Desember 2019, wabah pneumonia yang disebabkan oleh virus corona terjadi di Wuhan, provinsi Hubei, dan telah menyebar dengan cepat ke seluruh Cina. Wabah ini menyebar begitu cepat hingga ke seluruh dunia. Wabah ini diberi nama Corona Virus Disease 2019 (COVID-19) yang disebabkan oleh Severe Acute Respiratory Syndrome Coronavirus-2 (SARS-CoV-2). Pada 30 Januari 2020, WHO menyatakan wabah SARS-CoV-2 sebagai Kesehatan Masyarakat Darurat dari Kepedulian Internasional. Pandemi ini menjadi duka dan beban yang sangat berat bagi masyarakat dunia dan Indonesia. Berdasarkan data dari Kementerian Kesehatan Republik Indonesia, jumlah kasus corona di dunia telah mencapai 5,21 Juta dengan jumlah sembuh 2.05 Juta dan meninggal mencapai 338 Ribu, sedangkan kasus di Indonesia telah mencapai 20,796 kasus dengan jumlah sembuh 5,057 dan meninggal 1,326. Data yang didapat berasal dari beberapa Peraturan dan beberapa peraturan dan kebijakan lainnya, serta fenomena yang terjadi di lapangan. Hasil penelitian menyatakan bahwa Indonesia sudah mengalami kondisi dimana kekhawatiran masyarakat terhadap covid-19 cukup besar, sehingga diperlukan kebijakan pemerintah untuk melakukan Lockdown, sebagai upaya memutus mata rantai penyebaran virus COVID-19. Awalnya pemerintah tidak mengikuti cara yang digunakan oleh beberapa negara lainnya terkait informasi yang diberikan mengenai virus COVID-19, untuk meminimalisir adanya berita Hoax dari segelintir orang yang tidak bertanggung jawab.
\end{abstract}

Kata kunci : COVID-19, pneumonia, Lockdown

\begin{abstract}
In December 2019, a pneumonic outbreak caused by the virus occurred in Wuhan, Hubei province. This epidemic spread so quickly throughout the world. This pandemic is a great sorrow and burden for the world Indonesia. The data obtained comes from several regulations and several other regulations and policies, as well as phenomena that occur in the field. so that a government policy to lockdown was needed, as an effort to break the chain of the spread of the virus. Initially the government did not follow the method used by several other countries related to information provided about the COVID-19.
\end{abstract}


Keyword: COVID-19, pneumonia, Lockdown

\section{PENDAHULUAN}

Penyebaran virus tidak diketahui keberadaanya akan sampai di Indonesia yang hinga sampai saat ini. Keberadaan virus sangat meresahkan karena menimbulkan kekhawatiran masyarakat, dengan adanya virus ini diadakan karantina terhadap warga yang pernah melakukan perjalanan ke wilayah terinfeksi. Sehingga masyarakat tidak lagi menganggap dengan menyepelekan virus ini. Maka dari itu aspek hukum dalam penanganan mendapatkan pelayanan kesehatan Tertuang dalam Pasal $28 \mathrm{H}$ ayat (1) Undang - Undang Dasar 1945. kesehatan adalah kebutuhan dasar manusia yang dijamin hak nya secara konstitusional Kesehatan adalah faktor penentu bagi kesejahteraan sosial (Yunus, Rezki, 2020: 229)

Kebijakan yang dikeluarkan pemerintah adanya Social Distancing yang dimungkinkan untuk mengurangi atau menghambat penyebaran virus. Dan kebijakan ini sangat efektif dengan mencegah orang sakit melakukan kontak langsung kepada orang lainnya yang tidak sakit sehingga mencegah penularan. Begitu juga tenaga kesehatan berupaya mencegah untuk bertambahnya orang yang terifeksi dan perlu adanya jaminan perlindungan dan keselamatan kerja bagi tenaga medis dalam penanganan Corona Virus Disease 2019 (COVID-19). Kebijakan terkait pelayanan kesehatan dapat dikatakan sebagai aspek penting dalam kondisi dimasyarakat sekarang (Yunus, Rezki, 2020: 228)

Corona Virus Disease 2019 (COVID-19) adalah keluarga besar virus yang dapat menyebabkan penyakit pada hewan atau manusia. Pada manusia, beberapa corona virus diketahui menyebabkan infeksi pernafasan mulai dari flu biasa hingga penyakit yang lebih parah seperti Middle East Respiratory Syndrome (MERS) dan Serve Acute Respiratory Syndrome (SARS) dan corona virus yang terbaru adalah yang menyebabkan COVID-19. COVID-19 adalah penyakit menular yang disebabkan oleh corona virus yang baru ditemukan. Virus dan penyakit baru ini tidak diketahui 
sebelum wabah dimulai di Wuhan pada desember 2019. COVID-19 ini sekarang menjadi pandemic yang menyerang semua negara yang ada di dunia. Virus COVID-19 bisa menimbulkan beragam gejala pada pengidapnya. Infeksi COVID-19 disebabkan oleh virus corona itu sendiri. Kebanyakan virus corona menyebar seperti virus lain pada umumnya, seperti melalui Percikan air liur pengidap (bantuk dan bersin), Menyentuh tangan atau wajah orang yang terinfeksi, Menyentuh mata, hidung, atau mulut setelah memegang barang yang terkena percikan air liur pengidap virus corona, Tinja atau feses (jarang terjadi). Khusus untuk COVID-19, masa inkubasi belum diketahui secara pasti. Namun, rata-rata gejala yang timbul setelah 2-14 hari setelah virus pertama masuk ke dalam tubuh. Di samping itu, metode transmisi COVID-19 juga belum diketahui dengan pasti. Awalnya, virus corona jenis COVID-19 diduga bersumber dari hewan. COVID-19 merupakan virus yang beredar pada beberapa hewan, termasuk unta, kucing, dan kelelawar. Sebenarnya virus ini jarang sekali berevolusi dan menginfeksi manusia dan menyebar ke individu lainnya. Namun, kasus di Tiongkok kini menjadi bukti nyata kalau virus ini bisa menyebar dari hewan ke manusia. Bahkan, kini penularannya bisa dari manusia ke manusia.

Awal mula Virus corona diketahui pertama kali muncul di pasar hewan dan makanan laut di kota Wuhan, China pada akhir desember 2019 lalu. Dilaporkan kemudian bahwa banyak pasien yang menderita virus ini dan ternyata terkait dengan pasar hewan dan makanan laut tersebut. Orang pertama yang jatuh sakit akibat virus ini juga diketahui merupakan para pedagang di pasar itu. (Dikutip dari $B B C$, koresponden kesehatan dan sains $B B C$, Michelle Roberts and James Gallager) mengatakan, di pasar grosir hewan dan makanan laut tersebut dijual hewan liar seperti ular, kelelawar, dan ayam. Mereka menduga virus corona baru ini hampir dapat dipastikan berasal dari ular. Diduga pula virus ini menyebar dari hewan ke manusia, dan kemudian dari manusia ke manusia. China tercatat sebagai negara yang pertama kali melaporkan kasus 
COVID-19di dunia. Pada penghujung tahun 2019, kantor organisasi kesehatan dunia (WHO) di China mendapat pemberitahuan tentang adanya sejenis pneumonia yang penyebabnya tidak diketahui. Infeksi pernafasan akut yang menyerang paru-paru itu terdeteksi di kota Wuhan, Provinsi Hubei, China. Menurut pihak berwenang, beberapa pasien adalah pedagang yang beroperasi di pasar ikan Huanan.

Penyebaran COVID-19 di Indonesia, Pemerintah mengumumkan secara resmi kasus COVID-19 pertama di Indonesia pada tanggal 2 maret 2020. Dua warga Indonesia yang positif mengatakan bahwa melakukan kontak langsung dengan warga Negara Jepang yang sedang berkunjung ke Indonesia. Tanggal 11 maret 2020, untuk pertama kalinya ada kasus meninggal diakibatkan karena virus corona tersebut. Korban yang meninggal adalah pria berusia 59 tahun warga asal solo. Diketahui dia tertular setelah menghadiri seminar di Bogor pada bulan Februari. Penyebaran virus corona di Indonesia ini tersebar di 34 provinsi di Indonesia. Per hari ini, jawa timur mencatat kasus baru terbanyak di Indonesia dengan jumlah 223 kasus, sehingga total 3.886 kasus.

Dalam hal ini, Penegakan Hukum di awal munculnya virus di Indonesia. Pemerintah Indonesia di tinjau berdasarkan Pasal 154 Undang

- Undang Nomor 36 tahun 2009 tentang Kesehatan, menyatakan Pemerintah wajib mengumumkan bagian wilayah yang menjadi sumber terjangkitnya penularan penyakit ke banyak masyarakat. Pemerintah wajib mengungkap jenis dari penyakit yang penularannya menyebar dengan cepat. Fakta dari Pemerintah dalam melindungi jaminan kesehatan masyarakat dikatakan lamban untuk menyebarkan informasi terkait kasus yang memakan korban banyak karena adanya virus yang sangat berbahaya ini. Sehingga dalam Pelayanan Kesehatan yang dilakukan tenaga medis bisa dikatakan hampir tidak mampu karena disebabkan banyaknya pasien yang dinyatakan Positif COVID-19. Berdasarkan uraian diatas, maka akan dibahas mengenai bagaimana awal terjadinya penyebaran virus begitu cepat di 
inodnesia dan bagaimana pelayanan kesehatan untuk masyarakat Indonesia dengan adanya keterlambatan informasi dalam mengungkapkan terjadinya penyebaran virus COVID-19.

Penelitian ini merupakan penelitian hukum normatif. Yang dimana menggunakan peraturan peraturan, perundang - undangan, dan pendapat - pendapat para sarjana. Sedangkan data sekundernya adalah bahan pustaka lainnya yang berkaitan dengan bahasan mengenai Pelayanan Kesehatan terhadap Hukum Kesehatan.

\section{PEMBAHASAN}

Hal yang perlu ditegaskan, beberapa virus corona dapat menyebabkan gejala yang parah. Infeksinya dapat berubah menjadi bronkitis dan pneumonia disebabkan oleh COVID-19, yang mengakibatkan gejala seperti: 1) Demam yang mungkin cukup tinggi bila pasien mengidap pneumonia. 2) Batuk dengan lendir 3) sesak napas 4) Nyeri dada atau sesak saat bernapas dan batuk. Gejala yang muncul ini bergantung pada jenis virus yang menyerang, dan seberapa serius infeksi yang terjadi. Berikut beberapa gejala virus COVID-19 yang terbilang ringan Hidung beringus 2) Sakit kepala 3) Batuk 4) Sakit tenggorokan 5) Demam 6) Merasa tidak enak badan. Untuk mendiagnosis infeksi virus corona, dokter akan mengawali dengan anamnesis atau wawancara medis. Di sini dokter akan menanyakan seputar gejala atau keluhan yang dialami pasien. Selain itu, dokter juga akan melakukan pemeriksaan fisik, dan pemeriksaan darah untuk membantu menegakkan diagnosis. Dokter mungkin juga akan melakukan tes dahak, mengambil sampel dari tenggorokan, atau spesimen pernapasan lainnya. Untuk kasus yang diduga infeksi novel corona virus, dokter akan melakukan swab tenggorokan, DPL, fungsi hepar, fungsi ginjal, dan PCT/CRP. Sebagaimana dokter berkewajiban untuk bertanggungjawab memberikan pelayanan kesehatan tidak terenca (Patittingi, 2018: 55).

Tak ada perawatan khusus untuk mengatasi infeksi virus corona. Umumnya pengidap akan pulih dengan sendirinya. Namun, ada beberapa upaya yang bisa dilakukan untuk meredakan gejala infeksi virus 
corona. Contohnya: Pertama, Minum obat yang dijual bebas untuk mengurangi rasa sakit, demam, dan batuk. Namun, jangan berikan aspirin pada anak-anak. Selain itu, jangan berikan obat batuk pada anak di bawah empat tahun. Kedua, Gunakan pelembap ruangan atau mandi air panas untuk membantu meredakan sakit tenggorokan dan batuk. Ketiga, Perbanyak istirahat. Keempat, Perbanyak asupan cairan tubuh. Kelima, Jika merasa khawatir dengan gejala yang dialami, segeralah hubungi penyedia layanan kesehatan terdekat.

Bila pasien mengidap infeksi COVID-19, dokter akan merujuk ke Rumah Sakit Rujukan yang telah ditunjuk oleh Dinas Kesehatan (Dinkes) setempat. Bila tidak bisa dirujuk karena beberapa alasan, dokter akan melakukan: Pertama, tindakan Isolasi. Kedua, Serial foto toraks sesuai indikasi. Ketiga, Terapi simptomatik. Keempat, Terapi cairan. Kelima, Ventilator mekanik (bila gagal napas). Keenam, Bila ada disertai infeksi bakteri, dapat diberikan antibiotik.

\footnotetext{
Sampai saat ini belum ada vaksin untuk mencegah
}

infeksi COVID-19. Namun, setidaknya ada beberapa cara yang bisa dilakukan untuk mengurangi risiko terjangkit virus ini. Berikut upaya yang bisa dilakukan: 1) Sering-seringlah mencuci tangan dengan sabun dan air selama 20 detik hingga bersih. 2) Hindari menyentuh wajah, hidung, atau mulut saat tangan dalam keadaan kotor atau belum dicuci. 3) Hindari kontak langsung atau berdekatan dengan orang yang sakit. 4) Hindari menyentuh hewan atau unggas liar. 5) Membersihkan dan mensterilkan permukaan benda yang sering digunakan. 6) Tutup hidung dan mulut ketika bersin atau batuk dengan tisu. Kemudian, buanglah tisu dan cuci tangan hingga bersih. 7) Jangan keluar rumah dalam keadaan sakit. 8) Kenakan masker dan segera berobat ke fasilitas kesehatan ketika mengalami gejala penyakit saluran napas. Berikut data sebaran virus corona di berbagai daerah di Indonesia persenin (25/5/2020) berdasarkan laporan dari data akun Twitter@BNPB_Indonesia 


\begin{tabular}{|c|c|c|c|c|c|c|c|c|c|c|}
\hline \multirow[t]{2}{*}{ NO } & \multirow[t]{2}{*}{ PROVINSI } & \multicolumn{3}{|c|}{$\begin{array}{c}\text { JUMLAH KASUS } \\
\text { TANGGAL } 25 \text { MEI } \\
2020\end{array}$} & \multicolumn{3}{|c|}{$\begin{array}{c}\text { JUMLAH KASUS } \\
\text { DENGAN } \\
\text { FOLLOWUP } \\
\text { SPESIMEN 2X } \\
\text { NEGATIF }\end{array}$} & \multicolumn{3}{|c|}{$\begin{array}{l}\text { JUMLAH KASUS } \\
\text { MENINGGAL }\end{array}$} \\
\hline & & $\begin{array}{c}\mathrm{S} / \mathrm{D} \\
24 \\
\mathrm{ME} \\
\mathrm{I} \\
202 \\
0\end{array}$ & $\begin{array}{c}25 \\
\text { MEI } \\
2020\end{array}$ & $\begin{array}{l}\mathrm{KU} \\
\mathrm{M}\end{array}$ & $\begin{array}{c}\text { S/D } \\
24 \\
\text { MEI } \\
2020\end{array}$ & $\begin{array}{c}25 \\
\text { MEI } \\
2020\end{array}$ & $\begin{array}{l}\mathrm{KU} \\
\mathrm{M}\end{array}$ & $\begin{array}{c}\text { S/D } \\
24 \\
\text { MEI } \\
2020\end{array}$ & $\begin{array}{c}25 \\
\text { MEI } \\
2020\end{array}$ & $\overline{\text { KUM }}$ \\
\hline 1 & ACEH & 19 & 0 & 19 & 17 & 0 & 17 & 1 & 0 & 1 \\
\hline 2 & BALI & 394 & 2 & 396 & 293 & 2 & 295 & 4 & 0 & 4 \\
\hline 3 & BANTEN & 789 & 0 & 789 & 176 & 0 & 176 & 66 & 0 & 66 \\
\hline 4 & BANGKA ELITUNG & 39 & 0 & 39 & 27 & 0 & 27 & 1 & 0 & 1 \\
\hline 5 & BENGKULU & 69 & 0 & 69 & 9 & 0 & 9 & 2 & 0 & 2 \\
\hline 6 & D YOGYAKARTA & 226 & 0 & 226 & 122 & 2 & 124 & 8 & 0 & 8 \\
\hline 7 & DKI JAKARTA & $\begin{array}{c}663 \\
4\end{array}$ & 75 & 6709 & 1586 & 69 & 1655 & 501 & 0 & 501 \\
\hline 8 & JAMBI & 95 & 2 & 97 & 13 & 2 & 15 & 0 & 0 & $\mathbf{0}$ \\
\hline 9 & JAWA BARAT & $\begin{array}{c}209 \\
1\end{array}$ & 22 & 2113 & 479 & 0 & 479 & 128 & 0 & 128 \\
\hline 10 & JAWA TENGAH & $\begin{array}{c}130 \\
9\end{array}$ & 2 & 1311 & 259 & 1 & 260 & 70 & 0 & 70 \\
\hline 11 & JAWA TIMUR & $\begin{array}{c}366 \\
3\end{array}$ & 223 & 3886 & 465 & 24 & 489 & 283 & 9 & 292 \\
\hline 12 & KALIMANTAN BARAT & 168 & 7 & 175 & 38 & 5 & 43 & 4 & 0 & 4 \\
\hline 13 & KALIMANTAN TIMUR & 276 & 0 & 276 & 105 & 12 & 117 & 3 & 0 & 3 \\
\hline 14 & KALIMANTAN TENGAH & 308 & 2 & 310 & 130 & 21 & 151 & 15 & 2 & 17 \\
\hline 15 & $\begin{array}{l}\text { KALIMANTAN } \\
\text { SELATAN } \\
\end{array}$ & 599 & 30 & 602 & 77 & 3 & 80 & 59 & 2 & 61 \\
\hline 16 & KALIMANTAN UTARA & 164 & 0 & 164 & 59 & 8 & 67 & 1 & 0 & 1 \\
\hline 17 & KEPULAUAN RIAU & 154 & 0 & 154 & 87 & 1 & 88 & 12 & 0 & 12 \\
\hline 18 & $\begin{array}{l}\text { NUSA TENGGARA } \\
\text { BARAT }\end{array}$ & 478 & 0 & 478 & 227 & 31 & 258 & 8 & 0 & 8 \\
\hline 19 & SUMATERA SELATAN & 736 & 76 & 812 & 102 & 10 & 112 & 25 & 0 & 25 \\
\hline 20 & SUMATERA BARAT & 478 & 0 & 478 & 180 & 6 & 186 & 24 & 0 & 24 \\
\hline 21 & SULAWESI UTARA & 230 & 9 & 239 & 34 & 0 & 34 & 15 & 3 & 18 \\
\hline 22 & SUMATERA UTARA & 311 & 4 & 315 & 108 & 5 & 113 & 33 & 0 & 33 \\
\hline 23 & SULAWESI TENGGARA & 215 & 0 & 215 & 51 & 0 & 51 & 4 & 0 & 4 \\
\hline 24 & SULAWESI SELATAN & $\begin{array}{c}129 \\
6\end{array}$ & 23 & 1319 & 456 & 6 & 462 & 64 & 3 & 66 \\
\hline 25 & SULAWESI TENGAH & 121 & 0 & 121 & 46 & 0 & 46 & 4 & 0 & 4 \\
\hline 26 & LAMPUNG & 109 & 7 & 116 & 38 & 2 & 40 & 7 & 0 & 7 \\
\hline 27 & RIAU & 111 & 0 & 111 & 66 & 0 & 66 & 6 & 0 & 6 \\
\hline 28 & MALUKU UTARA & 100 & 7 & 107 & 12 & 2 & 14 & 5 & 0 & 5 \\
\hline 29 & MALUKU & 159 & 1 & 160 & 22 & 5 & 27 & 7 & 0 & 7 \\
\hline 30 & PAPUA BARAT & 130 & 0 & 130 & 19 & 3 & 22 & 2 & 0 & 2 \\
\hline 31 & PAPUA & 556 & 11 & 567 & 48 & 20 & 68 & 6 & 0 & 6 \\
\hline 32 & SULAWESI BARAT & 86 & 0 & 86 & 27 & 0 & 27 & 2 & 0 & 2 \\
\hline 33 & $\begin{array}{l}\text { NUSA TENGGARA } \\
\text { TIMUR }\end{array}$ & 79 & 3 & 82 & 6 & 0 & 6 & 1 & 0 & 1 \\
\hline \multirow[t]{3}{*}{34} & GORONTALO & 58 & 0 & 58 & 18 & 0 & 18 & 2 & 0 & 2 \\
\hline & $\begin{array}{l}\text { Dalam Proses Verifikasi di } \\
\text { Lapangan }\end{array}$ & 21 & 0 & 21 & 0 & 0 & $\mathbf{0}$ & 0 & 0 & $\mathbf{0}$ \\
\hline & TOTAL & $\begin{array}{c}222 \\
71\end{array}$ & 479 & $\begin{array}{c}2275 \\
0\end{array}$ & 5402 & 240 & 5642 & 1372 & 19 & 1391 \\
\hline
\end{tabular}


suplemen sebagai bentuk pencegahan

Selain itu, juga bisa perkuat dari virus ini.

sistem kekebalan tubuh dengan

konsumsi vitamin dan

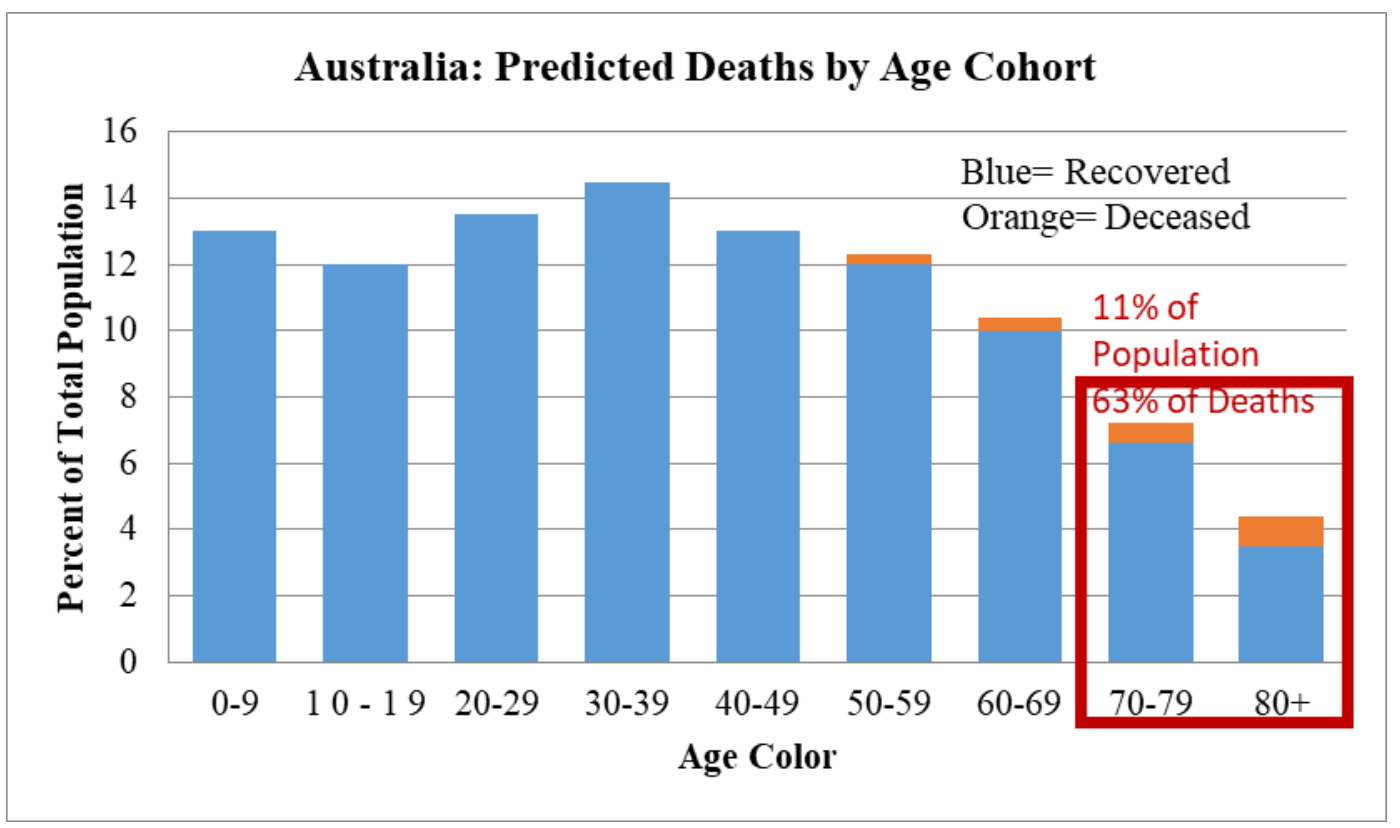

Data terkini menunjukkan bahwa lansia paling beresiko

Pemerintah dinilai terlambat mengantisipasi corona virus Kepala Pusat Pengendalian Operasi BNPB Bambang Surya Putra mengatakan, keterlambatan merespons masalah COVID-19, ternyata memengaruhi proses pendataan dan manajemen komunikasi publik. Imbasnya, Indonesia sulit memperoleh berbagai peralatan ihwal penanganan COVID19. Di sisi lain, Gugus Tugas baru dibentuk pada 13 Maret 2020, berdasarkan Keputusan Presiden
Nomor 7 Tahun 2020 tentang Gugus

Tugas Percepatan Penanganan

Corona Virus Disease 2019

Kemudian diturunkan dalam

Keputusan Kepala Badan Nasional Penanggulangan Bencana Nomor 13.

Keterlambatan merespons kemudian berdampak kepada kesulitan memperoleh peralatan yang dibutuhkan untuk melawan COVID19. Sehingga pemerintah melakukan segala cara. Dari mulai berdiplomasi ke berbagai negara, lewat jalur bisnis 
atau komersial, hingga berhubungan dengan intelijen. Indonesia dalam kondisi yang tidak siap dan terkejut dengan kecepatan penularan COVID-19. Ketidaksiapan juga terkait ketersediaan kebutuhan peralatan dan pendataan yang sangat memengaruhi penanganan COVID19. Hal itu juga memengaruhi komunikasi publik dan pengambilan kebijakan yang tepat. Walhasil, masyarakat bingung harus bersikap seperti apa. Di sisi lain, pendataan juga terkendala ego sektoral dan birokrasi yang panjang.

\section{Upaya penanggulangan} berbagai macam seperti pemeriksaan, pengobatan, perawatan, serta melakukan isolasi penderita yang dinyatakan positif begitu juga termasuk tindakan kekarantinaan. Kebijakan Pemerintah telah menerapkan kebijakan Pembatasan Sosial Berskala Besar (PSBB) untuk mencegah semakin meluasnya penularan COVID-19. Penerapan PSBB telah diatur dalam Peraturan Pemerintah Nomor 21 Tahun 2020 yang ditandatangani Presiden pada Selasa (31/3/2020). Sementara itu, detail teknis dan syarat-syarat mengenai PSBB dituangkan dalam
Peraturan Menteri Kesehatan

(Permenkes) RI Nomor 9 Tahun 2020 tentang Pedoman Pembatasan Sosial Berskala Besar Dalam Rangka Percepatan Penanganan Corona Virus Disease 2019 (COVID-19) yang ditandatangani oleh Menteri Kesehatan RI Terawan Agus Putranto. Adapula pada ketentuan Peraturan Perundang - undangan yang dituangkan dalam Undang Undang Nomor 6 tahun 2018 tentang Kekarantinaan Kesehatan dapat dikatakan lockdown adlah bagian dari ketentuan yang telah dibuat kebiajakan pada peraturan tersebut, pada peraturan tersebut membahas karatina kesehatan dipintu masuk dan di wilayah dilakukan kegiatan pengamatan penyakit dan berbagai faktor resiko kesehatan masyarakat terhadapa alat angkut, manusia, barang, dan/ lingkungan, serta respon terhadap kedaruratan kesehatan masyarakat dalam bentuk tindakan kekarantinaan kesehatan.

Dilihat dari peraturan tersebut, PSBB adalah pembatasan kegiatan tertentu penduduk dalam suatu wilayah yang diduga terinfeksi corona virus disease 2019 (COVID19) sedemikian rupa dapat dikatakan 
lockdown untuk mencegah Pelaksanaan Pembatasan Sosial kemungkinan penyebarannya. Agar Berskala Besar. Pergub tersebut bisa menetapkan PSBB, setiap memiliki 28 pasal yang mengatur wilayah pemberlakuan lockdown harus memenuhi kriteria: Jumlah kasus dan atau jumlah kematian akibat penyakit meningkat dan menyebar secara signifikan dan cepat ke beberapa wilayah. Terdapat kaitan epidemiologis dengan kejadian serupa di wilayah atau negara lain. Apabila PSBB dilaksanakan di suatu wilayah maka pelaksanaan PSBB meliputi beberapa hal, yakni peliburan tempat sekolah dan tempat kerja, pembatasan kegiatan keagamaan, pembatasan kegiatan di fasilitas umum. Namun, peliburan dan pembatasan tersebut dikecualikan untuk pelayanan tertentu seperti pelayanan kebutuhan bahan pangan, pelayanan kesehatan dan keuangan. Pembatasan juga dikecualikan untuk pelayanan kesehatan, pasar, toko, supermarket dan fasilitas kesehatan. Lalu di daerah manakah PSBB saat ini diterapkan?

Untuk pelaksanaan PSBB itu, Pemprov DKI Jakarta sudah menerbitkan Peraturan Gubernur Nomor 33 Tahun 2020 tentang seluruh kegiatan di Ibu Kota, baik kegiatan perekonomian, kegiatan sosial, kegiatan budaya, kegiatan keagamaan, maupun pendidikan Dia menegaskan bahwa selama masa pemberlakuan PSBB, seluruh masyarakat di Jakarta diwajibkan untuk mematuhi semua ketentuan. Surat Keputusan Menteri Kesehatan dengan nomor HK.01.07/ MENKES / 249 / 2020 tentang penetapan PSBB dibenarkan oleh Kepala Bagian Humas Pemkot Tangerang Buceu Gartina. "Surat sudah diterima,"

Surat yang telah ditanda tangani Menteri Kesehatan Terawan Agus Putranto pada Minggu 12 April 2020, yang isinya berbunyi terkait kewajiban wilayah Tangerang Raya untuk melaksanakan PSBB sesuai dengan kebijakan yang berlaku. PSBB dilaksanakan selama masa penyebaran terpanjang virus COVID-19 atau selama 14 hari dan dapat diperpanjang jika masih terdapat bukti penyebaran.

Berdasarkan keresahan Pemerintah dan Masyarakat atas tinggginya death rate COVID-19, 
maka perlu ditelisik lebih dalam penyebab tingginya tingkat kematian di Indonesia. Berikut adalah beberapa poin mengapa tingkat kematian karena Corona di Indonesia tinggi: Pemerintah Indonesia yang cenderung tertutup atas informasi Covid-19, Pada awalnya Pemerintah mengaku bahwa membatasi informasi adalah cara untuk mencegah kepanikan yang dapat terjadi di masyarakat. Menurut pemerintah, dengan akses informasi yang terbatas, maka situasi kondusif tetap dapat terjaga. Pemerintah dianggap membatasi dengan memberikan informasi yang minim terkait jumlah pasien dan lokasilokasi penularan Corona.

Penutupan akses yang dilakukan oleh pemerintah sebenarnya mendapat kecaman dari berbagai pihak. Arief Puyono salah satu politikus Gerindra menyatakan bahwa Pemerintah melanggar Undang-Undang Republik Indoensia Nomor 36 tahun 2009 tentang Kesehatan. Undang-Undang tersebut dalam Pasal 154 berbunyi "Pemerintah secara berkala menetapkan dan mengumumkan jenis dan persebaran penyakit yang berpotensi menular dan/atau menyebar dalam waktu yang singkat, serta menyebutkan daerah yang dapat menjadi sumber penularan". Sejumlah pemerintah daerah menyatakan tak tahu lengkap tentang informasi pasien positif Corona. Juru Bicara pemerintah khusus virus corona Achmad Yurianto bahkan menyatakan bahwa seorang dokter tidak memiliki kewajiban untuk memberikan informasi tentang kondisi pasien Corona kepada pemerintah daerah. Kebijakan pemerintah Indonesia sangat berbeda dengan kebijakan negara lain yang justru membuka informasi seluasluasnya mengenai Corona. Taiwan, negara yang berdekatan dengan negara dimana virus Corona pertama kali muncul menjadi salah satu negara yang membuka informasi seluas-luasnya terhadap warga negaranya. Dampak dari tindakan yang dilakukan oleh mereka adalah dapat ditekannya jumlah kasus hingga saat ini hanya berjumlah 108 kasus dengan total kematian 1 orang per 19 Maret 2020. Berkaca dari Taiwan, yang dilakukan oleh pemerintah Taiwan adalah ketika kasus corona mulai merebak di 
Tiongkok pada 31 Desember 2019, Pemerintah Taiwan langsung menguji kesehatan warganya yang memiliki catatan perjalanan ke Tiongkok. Padahal saat itu Corona belum dinyatakan sebagai penyakit yang mematikan.

Hal selanjutnya yang dilakukan oleh Taiwan adalah dengan sigap memberikan dan membagikan informasi kepada warganya, bahkan warga Taiwan sendiri setiap harinya menerima pengumuman mengenai potensi penularan virus Corona. Tidak hanya itu, pemerintah Taiwan juga mengedukasi warganya melalui televisi dan radio dengan membuat iklan selama satu jam. Iklan tersebut berisikan bagaiamana dan penyebaran serta bagaimana cara mencegah penularannya.

Masyarakat belum sepenuhnya menyadari pentingnya Social Distancing dan Penerapan PSBB, Social distancing saat ini sedang digaungkan oleh Pemerintah Indonesia sebagai salah satu cara pencegahan penyebaran virus Corona. Social distancing itu sendiri adalah bahwa masyarakat diminta untuk menghindari hadir di pertemuan besar atau kerumunan orang. Jika harus berada di sekitar orang, maka jaga jarak dengan orang lain sekitar 6 kaki (2 meter). Artinya, ada ruang yang cukup antara satu orang dengan orang lain sehingga menghilangkan rute transmisi virus. Mengingat penyebaran dan penularan virus Corona yang sangat cepat, maka social distanding dapat menjadi salah satu solusi efektif dalam mencegahnya. Ketua Pengurus Harian Yayasan Lembaga Konsumen Indonesia (YLKI) Tulus Abadi menilai bahwa imbauan pemerintah kepada masyarakat agar melakukan social distancing atau menjaga jarak, cukup efektif dalam mengurangi dampak penyebaran virus corona. Oleh karena itu, masyarakat seharusnya dapat mematuhi imbauan tersebut dengan sebaik mungkin.

Banyak orang yang tidak sadar bahwa dirinya terinfeksi, lalu bebas bepergian ke berbagai lokasi untuk menemui teman atau kerabatnya. Akibatnya, penyebaran virus ini semakin luas. Apalagi, virus ini sudah bisa menular ke orang lain, meskipun orang-orang yang terinfeksi tidak merasakan gejala 
yang berat. Mereka bisa saja merasa sehat dan hanya sedikit bersin-bersin atau flu, namun ternyata sudah terinfeksi Covid-19. Bayangkan jika orang yang terinfeksi itu masih tetap masuk kerja, sekolah, datang ke seminar, atau konser musik. Meski awalnya yang terinfeksi hanya satu orang, namun setelah menyebar, bisa saja ribuan orang lainnya yang berada di tempat tersebut, juga terinfeksi.

Memperlambat laju penyebaran virus dengan diadakan kebijakan lockdown juga penting agar orang yang sakit, tidak terinfeksi secara bersamaan. Tentu, akan jauh lebih mudah mengobati 4 orang yang terinfeksi dibandingkan dengan 1.000 orang sakit secara bersamaan. Dengan demikian, social distancing secara tidak langsung mampu membantu rumah sakit, laboratorium, maupun dokter dan tenaga medis lainnya agar tidak kewalahan menangani jumlah pasien Covid-19 yang melebihi kapasitas dan kemampuan daerah tersebut. Sehingga, semua pasien yang sakit bisa mendapatkan perawatan yang optimal.
Jika ketersediaan rumah sakit dan jumlah tenaga medis tidak seimbang dengan jumlah pasien, maka akan banyak pasien yang terinfeksi virus corona yang akhirnya tidak bisa mendapatkan perawatan yang layak. Akibatnya, angka kematian akan semakin tinggi.

Minimnya

Fasilitas

Kesehatan, Tak bisa dipungkiri bahwa fasilitas kesehatan yang mumpuni dapat menjadi tolok ukur kesiapan suatu negara dalam menghadapi berbagai ancaman kesehatan. Sayangnya, Indonesia masih menjadi salah satu negara dengan investasi pelayanan kesehatan yang rendah di dunia. Berkaca dari Korea Selatan Hampir 20.000 orang menjalani tes virus corona setiap hari di Korea Selatan, lebih banyak per kapita dibanding negara manapun di dunia. Pemrosesan hasil tes pun tidak menunggu waktu lama. Sampel dari hasil pemeriksaan langsung dikirimkan ke laboratorium dekat tempat pengambilan sampel. Di sana, para staf laboratorium bekerja bergiliran selama 24 jam sehari guna memprosesnya. Dalam hal ini indonesia dinilai masih kurang 
merata dalam menangani kasus virus ini karena keterlambatan sikap kesigapan, maka dari itu sering pada masyarakat terancam pelayanan kesehatannya karena investasi pelayan kesehatan rendah.

Jika upaya membatasi penyebaran virus corona diibaratkan peperangan, laboratorium inilah garis depannya. Korsel telah menciptakan jaringan 96 laboratorium milik pemerintah dan swasta untuk menguji keberadaan virus corona di antara individu-individu. Para pejabat kesehatan meyakini pendekatan ini menyelamatkan nyawa banyak orang. Tingkat kematian akibat virus corona di Korsel adalah 0,7\%. Adapun tingkat kematian akibat virus corona di dunia menurut Organisasi Kesehatan Dunia (WHO) mencapai 3,4\%. Korea selatan bahkan tidak kekurangan alat uji. Empat perusahaan mendapat izin pemerintah untuk membuatnya. Dengan demikian, Korsel kini punya kemampuan menguji 140.000 sampel setiap pekan. Prof Kwon di Korea Selatan meyakini akurasi tes Covid19 di Korsel sekitar 98\%. Kemampuan negara ini untuk menguji begitu banyak orang dalam waktu bersamaan menjadikan Korsel sebagai panutan bagi negara lainnya yang juga tengah berperang melawan virus corona.

Berkaca dari Korea Selatan, bagaimana dengan Indonesia? Tanpa pengetesan massal dan penambahan laboratorium yang memeriksa di Indonesia, sulit diketahui berapa sesungguhnya penderita Covid-19 di masyarakat. Sedikitnya pemeriksaan, membuat banyak orang yang positif Covid-19 terlambat dideteksi. Mereka dapat menularkan virus corona tanpa sadar, memperbanyak jumlah orang yang terinfeksi. Selain itu, lambatnya deteksi bisa meningkatkan angka kematian karena penderita tidak atau terlambat mendapatkan pengobatan. Indonesia perlu pemeriksaan Covid-19 yang massif untuk mengetahui besaran bencana Covid. Rendahnya jumlah yang dites (hingga 11 Maret) baru 736 spesimen yang diperiksamenyulitkan pemerintah dalam menilai besaran masalah Covid-19 dan perencanaan langkah penanggulangan.

Oleh karena itu beberapa pemerintah daerah menetapkan 
kebijakan PSBB dan social distancing untuk menahan laju penyebaran virus corona, sehingga kegiatan sehari-hari dibatasi dengan hanya bekerja dirumah dan belajar mengajar menggunakan sistem daring/online sampai sekarang bulan Mei ini. Presiden juga menghimbau untuk menunda kegiatan-kegiatan yang melibatkan banyak orang. Meski begitu penerapan social distancing dan PSBB saja belum cukup untuk mengatasi masalah penyebaran virus covid-19. Direktur jendral WHO Tenderos Adhanom Ghebreyesus mengatakan semua Negara harus mengombinasikan beberapa langkah penangan. Menurutnya langkah paling efektif adalah melakukan pemeriksaan, isolasi dan penelurusan kontak. Dengan begitu dapat memutus rantai penyebaran virus. Pelayanan kesehatan bagi masyarakat yang berada seharusnya mendapat perhatian dari pemerintah, karena adanya peraturan perundang undangan pada Pasal 28H ayat (1) Undang - Undang Dasar 1945 menyatakan bahwa setiap orang berhak untuk hidup sejahtera lahir dan batin, begitu juga bertempat tinggal dan mendapat lingkungan yang baik dan mendapat hak untuk terpenuhi pelayanan kesehatan. Indonesia seharusnya menyiapkan dan benar benar dalam memfasilitasi fasilitas kesehatan dari tingkat primer yaitu puskesmas, yang sering dijadikan rujukan masyarakat yang kurang mampu. Dapat dikatakan pemerintah pada saat mengabarkan bahwa penyebaran virus corona telah memasuki Indonesia, dalam pelayanan kesehatan dikatakan belum siap.

\section{Kesimpulan}

Hal yang terpenting dari intisari penulisan ini adalah bagaiamana pentingnya dalam menyampaikan masalah kesehatan untuk masyarakat agar menjaga kesehatan dan tetap bersikap tenang dalam kondisi seperti sekarang dengan semakin pesatnya penyebaran virus corona ini. Begitu pentingnya uga edukasi terhadap masyarakat yang masih awam akan pengetahuan tentang pemberlakuan PSBB /atau lockdown. beberapa pemerintah daerah menetapkan kebijakan PSBB dan social distancing untuk menahan laju penyebaran virus corona, sehingga 
kegiatan sehari-hari dibbatasi dengan hanya bekerja dirumah dan belajar mengajar menggunakan sistem daring/online sampai sekarang bulan Mei ini

Maka dalam penanganan penyebaran virus, kesehatan adalah kebutuhan dasar manusia yang dijamin hak nya secara konstitusional. Tertuang dalam Pasal $28 \mathrm{H}$ ayat (1) Undang - Undang Dasar 1945 menyatakan bahwa setiap orang berhak untuk hidup sejahtera lahir dan batin, begitu juga bertempat tinggal dan mendapat lingkungan yang baik dan mendapat hak untuk terpenuhi pelayanan kesehatan. PSBB dilaksanakan selama masa penyebaran terpanjang virus COVID-19 atau selama 14 hari dan dapat diperpanjang jika masih terdapat bukti penyebaran. Dari kebijakan pemerintah tersebut diadakan pula social distancing untuk memutus rantai virus corona. Begitu juga, dalam pelayanan kesehatan bagi masyarakat seharusnya berhak didapat dari pemerintah dan tetap memfasilitasi kesenjangan sosial.

\section{DAFTAR PUSTAKA}

\section{Buku}

Patittingi, Farida, 2017, Hukum

Kesehatan, Yogyakarta:

Litera

\section{Jurnal}

Yunus, Rezki. (2020), Kebijakan Pemberlakuan Lockdown Sebagai Antisipasi

Penyebaran Corona Virus Covid-, Jurnal Sosial \& Budaya UIN Syarif Hidayatullah Jakarta.

\section{Sumber Lain}

Denny Adhietya , Asal Mula dan Penyebaran Virus Corona dari Wuhan ke Seluruh Dunia, IDN TimesBali,https://bali.idntime s.com/health/medical/dennyadhietya/asal-muasal-danperjalanan-virus-corona-dariwuhan-ke-seluruh-duniaregional-bali/8, diakses pada tanggal 28 Mei 2020

Rizal Fadli, Coronavirus, Jakarta Selatan,https://www.halodoc. com/kesehatan/coronavirus

Danu Damarjati, Tingkat Kematian Pasien Corona di RI 8,3\%, 2 Kali Lipat Rata- rata Dunia, detiknews, https://news.detik.com/berita/ d-4944494/tingkat-kematianpasien-corona-di-ri-83-2-kalilipat-rata-rata-dunia

Abdillah, Soal Informasi Covid-19, Arief Poyuono: Pemerintah 
Langgar UU

Kesehatan,https://indopolitika

.com/soal-informasi-covid-

19-arief-d poyuono-

pemerintah-langgar-uu-

kesehatan/ 